\title{
1.タンパク質結晶構造解析法の進展
}

\section{MAD 法による構造解析の進展}

\author{
東京工業大学大学院生命理工学研究科 熊坂 崇 \\ 理化学研究所播磨研究所 山本雅貴
}

\begin{abstract}
Takashi KUMASAKA and Masaki YAMAMOTO: Development of Structure Analysis by MAD Method
\end{abstract}

The crystallographic phase problem had not been routinely solved in protein crystallography. Nowadays, MAD method is widely used for crystallographic determination of unknown protein structures, since the scope of MAD application has been extended by the use of synchrotron radiation facilities, protein expression techniques, and computational development. The method has paved the way to high-throughput structure determination of protein crystals and introduced to structural genomics study. We describe here a brief summary of MAD method and its experimental.

\section{1. はじめに}

構造ゲノミクスが現実のものとなった理由のひとつに, 多波長異常分散 (Multiwavelength Anomalous Diffraction; MAD）法(1-3) の進展によって新規構造のルーチン解析の 見通しが立つようになったことが挙げられるだろう。この 手法では，1つの結晶から得られる回折強度データで位相 問題を克服することができる。このため, 以前から使われ ている多重同形置換 (Multiple Isomorphous Replacement; MIR）法にあった諸問題をクリアすることができ，直接法 の適用が困難なタンパク質の結晶解析において, 今やタン パク質の新規構造を解析する主要な方法として利用され ている.この方法が近年劇的に普及した背景には，放射光 やタンパク質誘導体作成, 計算機技術などの周辺技術の発 展がある。これを踏まえ, 本稿では, 本法の理論的背景と 実際の適用についてまとめてみたい。

\section{2. 位相問題とMAD 法の原理}

低分子量の化合物についての結晶解析には, いわゆる直 接法が一般的に用いられている。高分解能の回折デー夕と 少ない原子数の試料については、確率論的なこの方法は有 効であり，1つの結晶から得られた1セットの回折強度デ 一タがあ机ば，多くの場合構造が決定できる。しかし，夕 ンパク質の場合は, 分解能や原子数の問題から, ほとんど の場合でこの方法が適用できないため，䀧なる作戦で臨ま ねばならない。

すでにアミノ酸配列が類似なタンバク質の構造が明ら かな場合，それを実測した結晶の格子小㤡罱する問題で ある分子置換法は，1セットの回折強度データがあれ机ば啇 用叮能である。しかし，構造の類似性や分解能，単位格子
中の分子数などの制約によって解析できない場合がある. もちろん, 類似構造のない新しいタンパク質の構造解析に は適用できない.

MIR 法は, 初めてタンパク質の構造を解析するのに成 功した手法である. Kendrewらはミオグロビン結晶に, 水 銀などの重原子イオンを特異的に結合させることによっ て生じる回折強度変化を観察し, その部分構造を抽出する ことを手がかりに，位相問題を解決した，その後の解析の 多くはこの方法で行われてきた.

MAD 法も位相決定の原理については,この MIR 法と変 わらず, 強度を変化させる部分構造に基づく作図 (Harker diagram) で位相が得られる.ただし, 強度を変化させる因 子が重原子の有無ではなく, 波長に依存した異常分散効果 である点が異なる。異常分散効果は, 固有振動をもつ軌道 上の電子に対する入射 X 線によって誘起される振動の共 鳴現象であるが，入射 X線の波長の変化に伴って回折強 度と位相を变化させる。一般的な回折実験に使われる 1.0 $\AA$ から $\mathrm{Cu} K_{\alpha}$ 線前後の波舆領域では, 鉄, 銅, 垔鉛などの $K$ 吸收端や水銀, 白金などの $L_{111}$ 吸收端が存在する -方, 夕 ンパク質を含む生体高分子の主要な構成原子である炭素, 窒素, 酸素, 硫黄では,この効果は無視できる.このことは, 導入した部分構造を抽出するのに適している.

この作図の原理は Karleによって定式化された.4) 1 種類 の異常散乱子を含む結晶について, 波長 $\lambda$ における反射 $\mathbf{h}$ とその Friedel 対-hに対する構造振幅 $|\lambda \mathbf{F}( \pm \mathbf{h})|$ は, 次式 で与えられる.

$$
\begin{aligned}
|\lambda \mathbf{F}( \pm \mathbf{h})|^{2}= & \left.\left.\right|^{\circ} \mathbf{F}_{\mathrm{T}}\right|^{2}+\left.\left.a(\lambda)\right|^{\circ} \mathbf{F}_{\mathrm{A}}\right|^{2}+\left.\boldsymbol{b}(\lambda)\right|^{\circ} \mathbf{F}_{\mathrm{T}} \|^{\circ} \mathbf{F}_{\mathrm{A}} \mid \cos \left(\phi_{\mathrm{T}}-\phi_{\mathrm{A}}\right) \\
& \pm\left.\mathrm{c}(\lambda)\right|^{\circ} \mathbf{F}_{\mathrm{T}} \|^{\circ} \mathbf{F}_{\mathrm{A}} \mid \sin \left(\phi_{\mathrm{T}}-\phi_{\mathrm{A}}\right)
\end{aligned}
$$


${ }^{\circ} \mathbf{F}_{\mathrm{T}} \mid$ と $\phi_{\mathrm{T}}$ はそれ以外の成分の構造振幅と位相であり, 通 常散乱因子 $f_{0}$, 珙常散乱の尖数項 $f^{\prime}$, 虚数項 $f^{\prime \prime}$ としたとき, $a(\lambda)=\left(f^{\prime 2}+f^{\prime \prime 2}\right) / f_{10^{2}} . b(\lambda)=2 f^{\prime} / f_{0}, c(\lambda)=2 f^{\prime \prime} / f_{0}$ とななる.

f"は位相の情報に直結しており，単波垃です系の間 題を解決することができる。この效果はBijvoetによって 絶対構造や位相の決定に利用された.5 その後Okaya Pepinskiによって,MAD法が位相洟定に利用できること がホされた。

しかし，タンパク質への応用はただちには行わ机なか った.これには, 異常分散効果の大きさが影響している.重 原子の導入によって得られる強度変化は, そのイオンの 電子数に比例するが, 例えば水銀原子が1つ格子に入った 場合, 占有率を 1 として最大 80 電子分の寄与があるが, 異 常分散効果の場合は波長を最適化してようやく 20 電子相 当程度であり，実験公で一般的に使わ机る $\mathrm{Cu} K_{\alpha}$ 線では 8 電子弱相当と小さくなる. 結局, タンパク質のような分子 量の大きな分子からなる結晶の回折強度变化としては, 核 種にもよるが数\%程度となり, 微弱な異常分散の信方を 抽出してこ机らの計算を谁める必要がある。このため, 波 垃の最適化が叮能な放射光施設が利朋できるようになっ て、尖現が叮能になった. Hendricksonらは1985 年ににSSRL にて Lamprey Hemoglobinの鉄原子。暴常分散效果を使 って，位相決定に成功した.7 その後, 第3 世代放射光施没 の利用，タンパク質発現精製技術の展開，言十算機の高洎速化 とソフトウェアの充実などがあいまって，現在に去って いる.

\section{3. 実験方法}

MAD 法の適用に限り話を進めたい。まず，異常散乱子 を含む結晶を作成する必要がある、鉄や銅，西鉛などを天 然に含む金属タンパク質の場合は, 利用できるX 線の波 長にもよるが，そのままの状態でMAD法が適用できる。 2 種類の金属を含むタンパク質では, その仿㯰を異常分散 効果から得ることができる.

重原子誘導体は，MAD法の候補である，良来の車原子 嶈人法が使える。ただし、MAD法だけを考える埸众，MIR

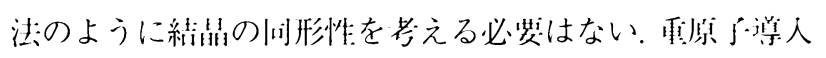
によって絬晶の状態(格子“分数や分子構造など) が変化し たとしても，1つの結鼠からデータが得られるので, 位相 決分には問題がない.したがって、これまで避けられてい た高濃度の重原子試薬溶液への浸漬や其結晶化もMAD 法には有効である。

最近では, 臭素など八ロゲン塩の溶液への浸漬8) も試み られている。高濃度臭化物塩溶液の条件に結晶基し，た だちに凍結する。これらのタンパク質への結令はほかの方 法に比べあまり強くないので, 圧斗・濃度の設定や, 曝露 後の凍結操作などによっては, 良い結果が得ら机ないこと もある.キセノンなどの希ガス9!も例は多くないが, 異常 日本結晶学公誌第 45 卷第 1 少 (2003)

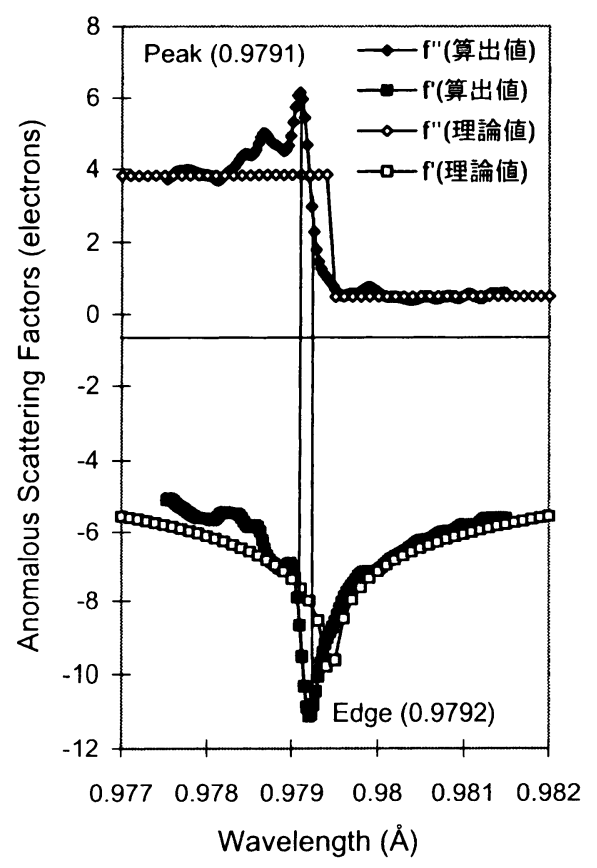

図 1 セレンの異常散乱肉子. (Anomalous scattering factors of selenium.) 実測データからの算出值と理論值い を小した $f$ ゙が敬大にになる Peak と, $f$ が构小になる

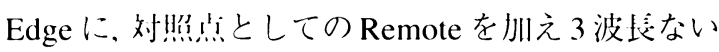
し4波主の收集が般的であるが，2波产でのデー 夕収集も行われている。算出にはChooch'12)を利用 した。

分散を利用した位相決定にも使われている。

タンパク質の発現技術によって, セレンをタンパク質に 導人する方法も広く使わ机ている.10)アミノ酸のセレン誘 導体 (セレノメチオニン・セレノシステイン) は, 異常分 散効果を利用するのに適当な原子である. 特定アミノ酸の 生合成系を阻止し，こ机らの誘導体をタンパク質合成にお いて取り込ませる方法である。誘導体タンパク質は溶解度 が落ち、発現がうまくいかないことや結晶化条件が变わっ てしまうこともあるが、確筷に導入できる方法である。ま た，異常分散差フーリエ四によってセレンを合むアミノ酸 の位㯰が特定でき，モデル構築を行うのに有效である。

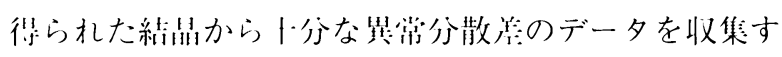

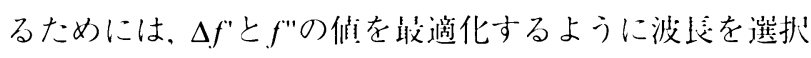
する必装がある。この鸿の見積もりは，吸收端の化学:シフ トや放射光ビームラインの装罱の腶定によって理論值い とは若「異なる值をとることがあるため, 起験的に行うべ きである. 異常·散乱お・の吸收端近傍で分光器の波言をスキ ヤンしながら蛍光X 線スペクトルを測定する(図1)。こ の際に, マルチチャンネルアナライザー (MCA) で蛍光 $\mathrm{X}$ 線のエネルギー成分を弁別し, 標的核種に由来する蛍光X 線が十分に観測されているかを事前に確認するとよい. 特 に，重原子溶液への浸漬によって得られる誘導体結晶で は，重原子化合物が含ま机ていない溶液にいったん㞍すバ ックソーキングを行ってから確認を行うと, 結合度をより 
正しく見積もることができる.こうして得られだ奏測スぺ クトルから異常分散項を見積もるためには, KramersKronig 変換を行う Chooch'21などのソフトウェアが利用で きる.

よりよい位相を得るためには, 複数の波垃から得ら机た 叫折デー夕の強度差が, 異常分散効果のみに由来すること が必要である。しかし、デー夕収集に伴う䛊差として，吸 収効果や放射線損傷などがある。前者はソフトゥェアによ るローカルスケーリングによる経験的な吸收補正が，後者 の抑制には低温結晶学の発達が成果を挙げた。しかし，高 精度デー夕を求めて高輝度放射光光源が使われるように なると, 液体空素低温で対処しきれない結晶が存在するこ とが明らかになってきたここれらの䛊差を最小限にするた めには，さまざまな工夫が必要になるが，この問題につい ては，回折デー夕の同質性の項で述べる. 得られた回折像 は通常用いら机る回折像処理ソフトウェアで回折強度デ 一夕に変換するが、全データで方位パラメー夕をそろえて 処理を行い，等価反射をマージせず，ローカルスケーリン グを行うようにする。また，プログラム REVISE'13)による 補正も効果がある。

位相決定は，MAD法が適用された当初には，前出の Karleの式に基づいて処理されていた。この式に基づき 2 波長以に:のデー夕収集によって得ら机る連立方程式を 解くことで, I ${ }^{\circ} \mathbf{F}_{\mathrm{T}} \mathrm{l},{ }^{\circ} \mathbf{F}_{\mathrm{A}} \mathrm{l},\left(\phi_{\mathrm{T}}-\phi_{\mathrm{A}}\right)$ の 3 変数を得ることがで きる. そして，異常散乱子のみからの寄与である| ${ }^{\circ} \mathbf{F}_{\mathrm{A}} \mid$ か ら、パターソン法や直接法などを適用し，その位置が決定 できる。そその結果 $\phi_{\mathrm{A}}$ が得られ机ば，全体の位相が求めら れるという算段である.この手順で計算するソフトウェア としてMADSYS パッケージいがある.しかし，データの 精度が高まるに伴い，このような特別な扱いをせず，従来 の MIR 法用のソフトゥェアで位相決定を行う試みもされ てきた.つまり，差パターソン罒から拾ったサイトを精密 化するという考え方である. SOLVE(4)や autoSHARP(5) は異常散乱子の部分構造決定から位相精密化まで自動的 に行える.メチオニンが多いタンパク質のセレン誘導体 や，八ロゲン塩による誘導体では，非対称単位中に数け一 100 個程度の原子が導入されてしまうこともあるが，これ らの自動化ソフトウェアで対処できている例も多い．

その後の位相改良やモデル構築などのステップはほか の方法と大差ない１つ留意するとす机ば，重原子誘導体 のデータしかない場合の取り扱いである. セレノメチオニ ン誘導体や重原子誘導体結晶のほうがよい分解能を与え る場合などがあり,これのみのデータでのモデル精密化も 行われている。

\section{4. 回折データの同質性}

MIR 法では，重原子誘導体のデータと元々のタンパク 質結晶のデータで結晶がそもそも異なるうえ，重原子を特
異的に結合させているため, 結晶格子や分子構造に若干の 違いが見られることもしばしばである。このため，高分解 能での位相決定は，一般に難しい。

しかしMAD法では，1つの結晶から全デー夕が得られ れば，その点を考える必要はないはずで，結晶の同形性に ついては問題がない．このため, 高分解能での位相決定も 可能になる。しかし、結晶の同形性以外に系統誤差を作り 出す原肉として, 結晶の外形などによるX線吸収の異方 性や放射線による損傷 161 などが問題となる。結晶外形や 結晶をマウントするループの形状などで, 吸収の効果が結 晶方位によって変化したり，データの収集中に放射線損傷 によって結晶が徐々に変化していくことで, 各デー夕の一 致度が悪化することになる. MIR 法でも問題になるデー タセット間の一致度は、強度差が小さいMAD法において は特に注意してかかる必要がある。

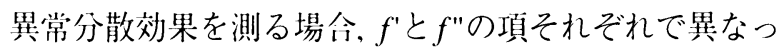
た配慮を必要とする．Hendricksonらは する目的でInverse Beam Geometry Setting を提案した.? このお法は，振動字真法によるデー夕収集において， Friedel 対が180 度異なる角度で収集できることに由来し ており、a度の问折像と $(180+\mathrm{a})$ 度の回折像を交互にと り准める。こ扎により、吸収の効果をほぼ等しくでき，ま た，関連するFriedel 対を近接した時間内に収集すること で,放射線損傷による経時的な系統誤差を減らそうとする ものである。しかしながら…万方のf'については，波長を迅 速かつ再現性よく変更できる必要があり，実現されていな かった：そこで、われわれは3つの波長をあらかじめ用意 し, 迅速に切り替えられる放射光ビームライン用分光器と してTrichromatorを開発した.17)

MAD法では，振動角と波長の組み合わせが最終的な位 相決定にも影響を与える。このことについて, 行った実験 を綃介したい.18)この分光器を使うことで, 振動角と波長 の順序を任意に組み合わせることができ, 波長入lでの $\mathrm{a}$ 度 の回折像に続いて, 波長での $\lambda 2$ での $\mathrm{a}$ 度の回折像を迅速に 收集できるようになった，その実際の効用について，波長 を固定して振動角を変えながらデー夕を収集する従来の方 法と，间一振動角で波長を変更しながらデー夕をとり進め る方法 (Trichromatic mode; 以下, 迅速波長切替法)で, そ のデータの統計を求め, 位相計算を行った。試料として, 六角柱状結晶が得ら机るセレノメチオニル化Chitosanase (ChoA) 19)を用いた。これは最高で $1.7 \AA$ の反射を与え， 比較的放射線損傷を受けにくい良好な結晶である。また， 結晶形状が棒状のため結晶の異なる位置にX線を当てる ことができ，比較実験に都合がよい．

図2に示すように，回折イメージごとの温度因子は, 経 時変化は従来法のほうが若干高いものの, トータルではさ ほど変わらない．しかし，イメージごとで温度因子の值 は、新しい手法では等価なイメージ間で一致しているのに 


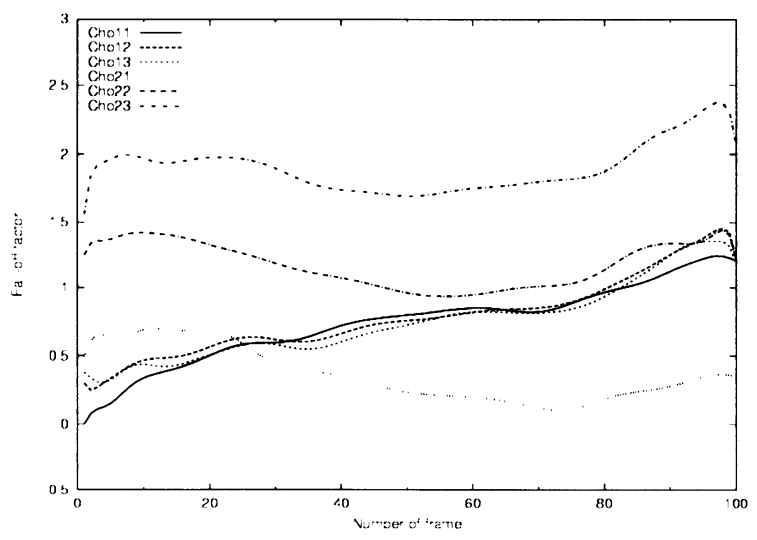

図2 箇なるデータ收集法によるフレーム温度因子の変 化. Variation of fall-off factors in the two data collection methods.) データの対応は表 1 を参照.

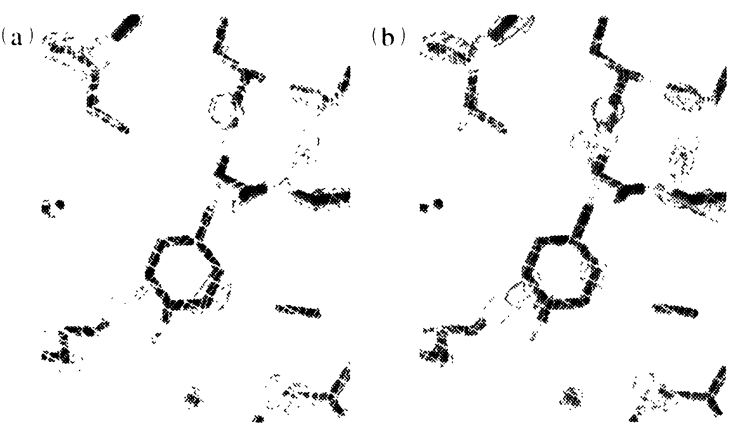

図3 異なるデータ収集汴による電了密度の違い。

(Comparison of the electron densities calculated with the two data collection methods.) (a) 计速波铭切替. (b) 佂来法. 前者では，チロシン側鎖の六員環の穴 が開いて見えている.

表 1 データ収集と位相缶の結果. (Statistics of Data Collection and Phase Calculation.)

\begin{tabular}{|c|c|c|c|c|c|c|}
\hline 收集泣 & \multicolumn{3}{|c|}{ 进速波良切替 (Trichromatic) } & \multicolumn{3}{|c|}{ 従米法 } \\
\hline Data & Choll & Chol2 & Chol3 & Cho.l & Cho22 & Cho23 \\
\hline & Remote & Peak & Edge & Remote & Peak & Edge \\
\hline 䘽测风射数 & 260.402 & 269,821 & 269,362 & 261.577 & 263.567 & 263.387 \\
\hline 独六父射数 & 65.579 & 66,482 & 66.428 & 65.695 & 66.480 & 66.449 \\
\hline$I / \sigma$ & 18.5 & 17.4 & 17.5 & 19.8 & 18.7 & 17.1 \\
\hline$R_{\text {matec }}\left(0_{0}\right)$ & 4.9 & 5.3 & 8.4 & 4.5 & 4.8 & 7.6 \\
\hline$\left.R_{1 \ldots} ! 0_{0}\right)$ & - & 5.7 & 4.8 & - & 6.4 & 7.8 \\
\hline$R_{\text {f ullt }}$ (iso) & & $0.82 / 0.84$ & $0.83 / 0.88$ & & $0.78 / 0.83$ & $0.76 / 0.86$ \\
\hline$R_{\text {(uill }}$ ano) & 0.94 & 0.91 & 0.99 & 0.94 & 0.91 & 0.99 \\
\hline Lack of closure (iso) & & $8.9 / 14.0$ & $8.1 / 12.5$ & & $11.4 / 14.7$ & $10.3 / 16.8$ \\
\hline Lack of closure (ano) & 8.98 & 16.56 & 7.32 & 8.11 & 15.91 & 6.37 \\
\hline Figure of merit & 0.4508 & & & 0.4887 & & \\
\hline $\begin{array}{l}\text { Phasing power } \\
\langle|\Delta \phi|\rangle\end{array}$ & $\begin{array}{c}1.82 /- \\
44.2\end{array}$ & $\begin{array}{c}1.19 / 0.82 \\
(33.9)\end{array}$ & $1.22 / 0.81$ & $\begin{array}{l}1.85 /- \\
47.8\end{array}$ & $\begin{array}{c}1.38 / 0.89 \\
(39.4)\end{array}$ & $1.40 / 0.90$ \\
\hline
\end{tabular}

対し，従来法では，その差がある值をもっている。この結 果，新しい手法では，波長間の一致度である $R_{\mathrm{iso}}$ が良い佃 をホした。しかし、f"については考慮されていないため, $R_{\text {merge }}$ はかえって患化し Friedel 対間の一致度が悪いこと を小している(表1)。

位相計算の統汁值にもその傾问は表机ているが，最終 的に得ら机た位相についてみると, 精密化したモデルか

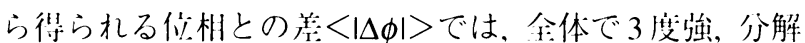
能範闻を限䇥すると最大で 7 度程度、モデルに近いことが 示された，その結果，電子密度网においても梌意な等が出 ており(図3)，このお法が有用であることを亦すことが できた。この結果から，このような特殊な光学系を使わな くとも波長の再現性が確保できれば，放射線損傷を考虑 して適当な範讲ごとに波長を変えながら行うことで，良 い結果が得られるものと理解できる.

\section{5. おわりに}

MAD 法は解析の迅速化・ルーチン化に大きな寄与を 果たしている.MAD法のさらなる進展としての異常分散
効果による位相決定という観点からは, 放射光の高輝度 X 線や高精度 X 線検出器の出現によるデー夕精度の向上と ともに,より簡便かつ迅速に位相決定に必要なデー夕を集 める方法について検㣙されている。ここでは述べなかった が, SAD (Single-wavelength Anomalous Diffraction) 法が

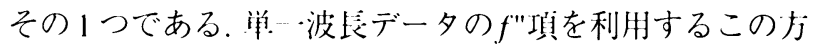
法は，原理的にBimodal な位相確摔分布から逃孔られず，

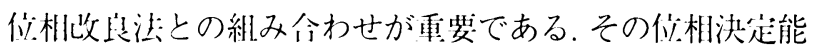
おについては，まだ結論が出ていないようであるが、デー 夕の片弶度を上げることでようやく位相が決定できるよ うな事例201も報告されており，より槀精度のデー夕仪集 が必要であることを小している. 単波長で位相の精度が足 りない場合は別波淁のデー夕を追加して測走するなど, 現 時点ではMAD 法との使い分けによって，より現実的な効 率化を四る必要があるだろう。また，タンパク質微小結晶 への適用や長波产X 線による硫黄などの比較的軽い原子 の異常分散効果の利用201は令後の課題の1つであり，こ れらを視野に人机て, 解析のルーチン化と迅速化をさらに 進めていく必装があるだろう。 


\section{文 献}

1) W. A. Hendrickson: Science 254. 51 (1991).

2) W. A. Hendrickson and C. M. Ogata: Methods En-ymol. 276. 494 (1997)

3) M. A. Walsh, G. Evans, R. Sanishvili, I. Dementieva and A. Joachimiak: Acta Cryst. D55, 1726 (1999).

4) J. Karle: Int. J. Quant. Chem. 7, 357 (1980).

5) J. M. Bijvoet: Proc. Acad. Sci. Amst. B52, 313 (1949).

6) Y. Okaya, R. Pepinsky: Phys. Rev. 103, 1645 (1956).

7) W. A. Hendrickson, J. L. Smith, R. P. Phizackerley and E. A. Merrit: Proteins 4, 77 (1988).

8) Z. Dauter and M. Dauter: Structure 9, R21-R26 (2001).

9) O. Sauer, A. Schmidt, C. Kratky: J. Appl. Cryst. 30, 476 (1997).

10) W. A. Hendrickson, J. R. Horton and D. M. LeMaster: EMBO J. 9, $1665(1990)$

11) S. Sasaki: KEK Report 88-14, I (1989).

12) G. Evans and R. F. Pettifer: J. Appl. Crvst. 34, 82 (2001).

13) F. Hai-fu, M. M. Woolfson and Y. Jia-xing: Proc. R. Soc. Lond. A442, 13 (1993).

14) T. Terwilliger and J. Brendzen: Acta Cryst. D55, 849 (1999).

15) E. de La Fortelle, G. Bricogne: Methods Enzymol. 276, 472 (1997).

16) C. Nave: Rad. Phys. Chem. 45, 483 (1995).

17) M. Yamamoto, T. Kumasaka, T. Fujisawa and T. Ueki: $J$. Synchr. Rad. 5, 414 (1998).

18) T. Kumasaka, M. Yamamoto, E. Yamashita, H. Moriyama and T. Ueki: Structure 10, 1205 (2002).

19) J. K. Park, K. Shimono, N. Ochiai, K. Shigeru, M. Kurita, Y. Ohta, K. Tanaka, H. Matsuda, M. Kawamukai: J. Bacteriol. 181, 6642 (1999).

20) M. S. Weiss, T. Sicker, R. Hilgenfeld: Structure 9, 771 (2001).
プロフィール

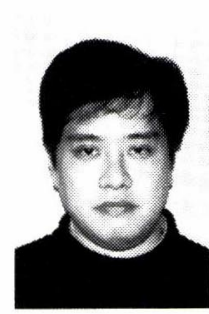

熊坂 等 Takashi KUMASAKA

東京「業大学大学院生命理厂学研究科分子生命科

学専攻

Department of Life Science, Tokyo Institute of Technology

干 226-8501 横浜甫緑区食津H町 4259

4259 Nagatsuta-cho, Midori-ku, Yokohama, 2268501 , Japan

TEL \& FAX. 045-924-5707

e-mail: tkumasak@bio.titech.ac.jp

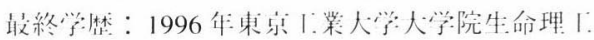

仾究科博土後期淉程修厂

势閏分野：タンパク筫絬昌兴:

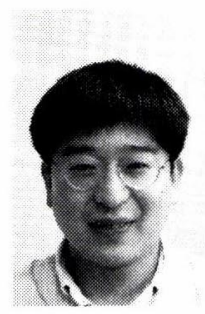

II本雅貴 Masaki YAMAMOTO

理化学研究所播磨研究所X 線下涉光学研究

X-ray Coherent Optics Laboratory, RIKEN Harima Institute

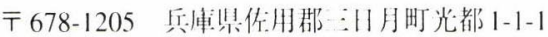

1-1-1 Kouto, Mikazuki, Sayo, Hyogo 678-1205,

Japan

TEL. 0791-58-2806, FAX. 0791-58-2807

e-mail: yamamoto@postman.riken.go.jp

最終学禁：1991年大防大学大学院棵学研究科博

上:後期棵程修了

専閒分野：放射光構遮牛:物“高 